\title{
Inheritance of Virulence, Construction of a Linkage Map, and Mapping Dominant Virulence Genes in Puccinia striiformis f. sp. tritici Through Characterization of a Sexual Population with Genotyping-by-Sequencing
}

\author{
Congying Yuan, Meinan Wang, Danniel Z. Skinner, Deven R. See, Chongjing Xia, Xinhong Guo, ${ }^{\dagger}$ and Xianming Chen ${ }^{\dagger}$
}

First and sixth authors: College of Biology, Hunan University, Changsha, Hunan 410082, China; first, second, fourth, fifth, and seventh authors: Department of Plant Pathology, Washington State University, Pullman 99164-6430; and third, fourth, and seventh authors: U.S. Department of Agriculture, Agricultural Research Service, Wheat Health, Genetics, and Quality Research Unit, Pullman, WA 99164-6430.

Accepted for publication 1 September 2017.

\begin{abstract}
Puccinia striiformis $\mathrm{f}$. sp. tritici, the wheat stripe rust pathogen, is a dikaryotic, biotrophic, and macrocyclic fungus. Genetic study of $P$. striiformis f. sp. tritici virulence was not possible until the recent discovery of Berberis spp. and Mahonia spp. as alternate hosts. To determine inheritance of virulence and map virulence genes, a segregating population of 119 isolates was developed by self-fertilizing $P$. striiformis f. sp. tritici isolate 08-220 (race PSTv11) on barberry leaves under controlled greenhouse conditions. The progeny isolates were phenotyped on a set of 29 wheat lines with single genes for racespecific resistance and genotyped with simple sequence repeat (SSR) markers, single nucleotide polymorphism (SNP) markers derived from secreted protein genes, and SNP markers from genotyping-by-sequencing (GBS). Using the GBS technique, 10,163 polymorphic GBS-SNP markers were identified. Clustering and principal component analysis grouped these markers into six genetic groups, and a genetic map, consisting of six linkage groups, was constructed with 805 markers. The six clusters or linkage groups resulting

from these analyses indicated a haploid chromosome number of six in P. striiformis f. sp. tritici. Through virulence testing of the progeny isolates, the parental isolate was found to be homozygous for the avirulence loci corresponding to resistance genes $Y r 5, Y r 10, Y r 15, Y r 24, Y r 32, Y r S P, Y r T r 1$, $Y r 45$, and $Y r 53$ and homozygous for the virulence locus corresponding to resistance gene $\mathrm{Yr} 41$. Segregation was observed for virulence phenotypes in response to the remaining 19 single-gene lines. A single dominant gene or two dominant genes with different nonallelic gene interactions were identified for each of the segregating virulence phenotypes. Of 27 dominant virulence genes identified, 17 were mapped to two chromosomes. Markers tightly linked to some of the virulence loci may facilitate further studies to clone these genes. The virulence genes and their inheritance information are useful for understanding the host-pathogen interactions and for selecting effective resistance genes or gene combinations for developing stripe rust resistant wheat cultivars.
\end{abstract}

Wheat stripe (yellow) rust, caused by Puccinia striiformis Westend. f. sp. tritici Erikss., is one of the most destructive fungal diseases of wheat worldwide (Chen 2005; Wellings 2011). The major approaches for controlling stripe rust is growing resistant cultivars and applying fungicides (Chen 2014). However, changes in virulence frequently occur in the pathogen population and fungicide applications generate additional costs and potentially are harmful to the environment (Chen 2013, 2014). Therefore, it is important to develop wheat cultivars with effective and durable resistance (Chen 2013; Johnson 1981).

On the basis of gene-for-gene relationships, the resistance phenotype of a host can be determined through the interaction between an avirulence (Avr) gene in the pathogen and its corresponding resistance (R) gene in the host (Flor 1965; Loegering 1978). In the host plant, a resistance gene may encode a putative receptor that triggers an effective defense response upon the recognition of the product of an avirulence gene in the pathogen (McDowell and Woffenden 2003). The wheat- $P$. striiformis f. sp. tritici pathosystem fits the gene-for-gene

${ }^{\dagger}$ Corresponding authors: X. M. Chen; E-mail: xianming@wsu.edu, and X. H. Guo; E-mail: gxh@hnu.edu.cn

Mention of trade names or commercial products in this publication is solely for the purpose of providing specific information and does not imply recommendation or endorsement by the U.S. Department of Agriculture. USDA is an equal opportunity provider and employer.

*The $\boldsymbol{e}$-Xtra logo stands for "electronic extra" and indicates that six supplementary figures and three supplementary tables are published online.

This article is in the public domain and not copyrightable. It may be freely reprinted with customary crediting of the source. The American Phytopathological Society, 2018. relationship. Close to 80 permanently named $\mathrm{Yr}$ (yellow rust) genes and more than 200 temporarily named genes or quantitative trait loci (QTL) for resistance to $P$. striiformis f. sp. tritici have been mapped to wheat chromosomes, and some of the resistance genes in wheat genotypes have been used to distinguish $P$. striiformis $\mathrm{f}$. sp. tritici races (Chen 2005, 2013; McIntosh et al. 2013; Rosewarne et al. 2013). Virulence of the pathogen has been studied by testing isolates on a set of wheat cultivars or single-gene lines for differentiating races (Chen 2005; Chen et al. 2002, 2010; Line 2002; Line and Qayoum 1992; Wan and Chen 2012, 2014; Wan et al. 2016). Avirulence genes have been described in different races based on tests with differential wheat lines. Based on characterization of natural P. striiformis f. sp. tritici populations using virulence tests and single-nucleotide polymorphism (SNP) markers developed from secreted protein (SP) genes, Xia et al. (2016b) identified SP-SNP markers associated with avirulence loci. It is likely that these associations are due to linkage disequilibrium caused by clonal reproduction and due to the limited number of markers utilized in these studies. No avirulence genes in $P$. striiformis f. sp. tritici previously have been mapped to chromosomes.

The stripe rust pathogen is a biotrophic obligate parasite in the basidiomycete group of fungi. The fungus has a heteroecious macrocyclic life cycle consisting of five spore stages (Zhao et al. 2016). It was not possible to study the genetics of $P$. striiformis $\mathrm{f}$. sp. tritici virulence until the recent discovery of barberry (Berberis spp.) and mahonia (Mahonia spp.) as alternate hosts (Jin et al. 2010; Wang and Chen 2013; Zhao et al. 2013). The alternate hosts can be used to study genetics of important traits, such as virulence, in the stripe rust pathogen.

Wang et al. (2012) obtained 29 progeny isolates through selffertilizing a U.S. P. striiformis f. sp. tritici isolate on barberry. The isolates segregated for 14 virulence loci. Rodriguez-Algaba et al. 
(2014) self-fertilized a European $P$. striiformis f. sp. tritici isolate and obtained 16 progeny isolates, which segregated for 14 simple sequence repeat (SSR) marker loci. These studies confirmed segregation following self-fertilization on the alternate host. More recently, Tian et al. (2016) developed a sexual population consisting of 118 progeny isolates by self-fertilizing a Chinese $P$. striiformis $\mathrm{f}$. sp. tritici isolate. They constructed a linkage map containing eight avirulence loci and 10 SSR markers. Some of the studies were limited by the small number of progeny isolates, and all of these studies were limited by the small number of markers resulting in limitations for linkage or association analysis.

The objectives of this study were to (i) develop a $P$. striiformis f. sp. tritici mapping population; (ii) characterize the population by virulence phenotyping on a set of wheat $\mathrm{Yr}$ single-gene lines and molecular genotyping using SSR markers and SNP makers based on secreted protein genes and genotyping-by-sequencing (GBS); (iii) construct a whole-genome linkage map for the pathogen; and (iv) identify markers associated with virulence loci. Our intention was that addressing these objectives would make progress in understanding the genetics of $P$. striiformis $\mathrm{f}$. sp. tritici virulence and establish foundational resources for further cloning genes for avirulence and other important traits. Such genetic information of the pathogen may lead to improving strategies for better control of stripe rust.

\section{MATERIALS AND METHODS}

Urediniospore multiplication and teliospore production. The parental isolate $08-220$ was originally collected from a wheat field in Pullman, Washington in 2008. The isolate was identified by Wan and Chen (2012) as race PST-127 using the 20 wheat cultivar differentials and as race PSTV-11 in this study using $18 \mathrm{Yr}$ single-gene line differentials (Wan and Chen 2014). PST-127, which was first identified in California and Washington in 2007 and has the broadest virulence spectrum based on the 20 wheat cultivar differentials, became one of the predominant races in the western United States in 2009 to 2011 (Chen et al. 2010; Wan and Chen 2012). Isolate 08-220 for PST-127 was selected for developing a sexual population, not due to its broad virulence but because it produces abundant telia under controlled greenhouse conditions. The original isolate was purified through three successive isolations each from a single uredinium. The purified isolate was tested on both the 20 cultivar and $18 \mathrm{Yr}$ single-gene differentials, and confirmed as PST-127 and PSTV-11, respectively.

Urediniospores of the purified isolate were increased on susceptible wheat cultivar Nugaines, which was developed by O. A. Vogel at Pullman, WA in 1965 (https://npgsweb.ars-grin.gov/gringlobal/ accessiondetail.aspx?id=1065472) and has been used to recover and increase urediniospores as it is susceptible to all $P$. striiformis $\mathrm{f}$. sp. tritici races identified thus far in the United States (Line and Qayoum 1992; Chen 2013). Seedlings at two-leaf stage, which had been grown in a rust-free greenhouse set at the diurnal cycle of 15 to $22^{\circ} \mathrm{C}$ and 8 -h dark/16-h light were inoculated with a spore/talc mixture (ratio 1:20). Inoculated plants were kept in a dew chamber for $24 \mathrm{~h}$ at $10^{\circ} \mathrm{C}$ in dark and then moved to a growth chamber set at a diurnal cycle of temperature gradually changing between $4^{\circ} \mathrm{C}$ at $2: 00$ a.m. and $20^{\circ} \mathrm{C}$ at 2:00 p.m. and $8 \mathrm{~h} / 16 \mathrm{~h}$ dark/light with $4^{\circ} \mathrm{C}$ occurring at the midpoint of the dark phase and $20^{\circ} \mathrm{C}$ at the midpoint of the light phase. Urediniospores were harvested 17 to 22 days after inoculation. Spring wheat cultivar Avocet Susceptible (AvS), which was used as a recurrent parent to develop $Y r$ near-isogenic lines (Wellings et al. 2004), was inoculated with urediniospores at the flag leaf stage and with sporulation induced under the same conditions as described above. Leaves with teliospores were collected about 30 days after inoculation, dried in a desiccator, and stored at $4^{\circ} \mathrm{C}$.

Developing a sexual population. Germination of teliospores, inoculation of young leaves of barberry with basidiospores, fertilization of receptive hyphae with pycniospores from different pycnia, collection of aeciospores from barberry leaves, inoculation of wheat leaves with aeciospores, and establishment of progeny urediniospore isolates from single uredinia were conducted using the procedures and conditions as described by Wang and Chen (2015). Briefly, 5-cm fragments of wheat leaves bearing telia were washed under tap water for $5 \mathrm{~min}$. After removing the epidermal layers with spatula and forceps, the leaf segments with exposed telia were placed on moist filter paper in Petri dishes. The Petri dishes were incubated at 10 to $12^{\circ} \mathrm{C}$ in dark for 3 days. Telia were checked under a microscope every day for basidiospore production. When abundant basidiospores were observed, teliospore/basidiospore suspensions in distilled water were made and brushed onto 10-day-old barberry leaves. The inoculated plants were kept in a dew chamber at $10^{\circ} \mathrm{C}$ in dark with $100 \%$ relative humidity for 36 to $48 \mathrm{~h}$. The plants were transferred to a growth chamber with the same temperature and light conditions as described above for growing wheat plants inoculated with urediniospores.

About 10 to 15 days after inoculation, pycniospores were transferred between pycnia with a sterile paint brush moistened with sterile distilled water. When aecia appeared on the opposite surface of barberry leaves about 7 to 10 days after fertilization, mature aecial cups were cut with a razor, placed into a 1.5-ml centrifuge tube containing sterile distilled water, and gently tapped with a toothpick for releasing aeciospores. The aeciospore suspension was spread on seedlings of wheat cultivar Nugaines with a sterile paint brush. The inoculated plants were kept in a dew chamber at $10^{\circ} \mathrm{C}$ for $24 \mathrm{~h}$, and then transferred to a growth chamber under the temperature and light conditions as described above. When chlorotic infection sites appeared on wheat leaves 6 to 9 days after inoculation, each plant with a single infection site was transplanted into a new pot and isolated from other pots by plastic booths. Each infection site was presumed to be produced from the infection of a single aeciospore and treated as one progeny isolate. To maximize the diversity of the progeny population, only one progeny isolate was obtained from each aecium. A total of 119 progeny isolates were obtained. Urediniospores of the parental isolate and progeny isolates were increased on Nugaines, and the increased urediniospores were used for virulence testing and DNA extraction.

Virulence testing. The parental isolate and progeny isolates were tested for response to a total of 29 wheat genotypes, including $20 \mathrm{Yr}$ near-isogenic lines (NILs) in the AvS background and 9 Yr single-gene lines (Table 1). Of the 29 wheat genotypes, 18 (numbers 1 to 18) are currently used for differentiating $P$. striiformis $\mathrm{f}$. sp. tritici races and 5 (numbers 19 to 23) as supplementary differentials (Wan and Chen 2014; Wan et al. 2016). For each line, five to seven seeds were planted for each isolate test. Two-leaf seedlings were inoculated with fresh urediniospores mixed with talc, incubated in the dew chamber, and grown in a growth chamber under the conditions as described above. Infection type (IT) data were recorded 18 days after inoculation based on a 0 to 9 scale (Line and Qayoum 1992). Isolates resulting in ITs 0 to 6 were considered avirulent (A), whereas those resulting in ITs 7 to 9 were considered virulent (V) (Wan and Chen 2014).

DNA extraction. DNA was extracted from fresh urediniospores using Omni Prep for Fungi Kits (G-Biosciences, Louis, MO) according to the manufacturer's specifications. DNA was quantified using a NanoDrop 1000 Spectrophotometer (Thermo Fisher Scientific) and 0.8\% agarose gel electrophoresis.

SSR and SNP genotyping. A total of 173 SSR and 199 secreted protein gene-derived SNP (SP-SNP) markers were used for genotyping the segregating population. Among the 173 SSR primer pairs, 92 were previously described (Bailey et al. 2013; Chen et al. 2009; Cheng et al. 2012; Enjalbert et al. 2002; Tian et al. 2016) and 81 were developed in this study (Supplementary Table S1). All of the 81 SSR markers designed in this study had three nucleotide motifs. The 33 SSR markers named PST_g001 to PST_g033 were developed based on the genomic sequence of race PST-78, while 48 (Pst127_gSSR_001 to Pst127_gSSR_048) were based on the genomic sequence of race PST127 (M. N. Wang and X. M. Chen, unpublished data). Of the 199 SPSNP markers developed in our lab, 99 were previously described (Xia et al. 2016a) and 100 were designed in this study (Supplementary Table S2). For genotyping with SSR markers, an M13 primer (5'-CACGA CGTTGTAAAACGAC) tag was added to the $5^{\prime}$ end of each forward 
primer for using fluorescence to detect polymerase chain reaction (PCR) products (Schuelke 2000). PCR was conducted in a volume of $12 \mu \mathrm{l}$, including $2 \mu \mathrm{l}$ of DNA $(50 \mathrm{ng} / \mu \mathrm{l}), 0.12 \mu \mathrm{l}$ of forward primer $(5 \mathrm{mM}), 0.6 \mu \mathrm{l}$ of reverse primer $(5 \mathrm{mM}), 1.2 \mu \mathrm{l}$ of $10 \times$ reaction buffer (with $15 \mathrm{mM} \mathrm{MgCl}$ ), $1.2 \mu \mathrm{l}$ of $\mathrm{MgCl}_{2}(25 \mathrm{mM}$ ), $0.96 \mu \mathrm{l}$ of dNTPs (2.5 mM each, Promega Inc.), $0.24 \mu 1$ of M13 primer with fluorescent dyes (10 mM, Applied Biosystems, Foster City, CA), $0.12 \mu \mathrm{l}$ of Taq DNA polymerase (5 U/ $\mu$ l, Promega Inc.), and $5.56 \mu$ of molecular biology grade (MBG) water (Bioexpress Inc.). PCR was run on an ABI 2720 Thermal Cycler (Applied Biosystems) programmed with an initial denaturation at $94^{\circ} \mathrm{C}$ for $5 \mathrm{~min}$, followed by 10 cycles of touchdown PCR at $94^{\circ} \mathrm{C}$ for $45 \mathrm{~s}, 63^{\circ} \mathrm{C}$ for 45 s with a decrease of $1^{\circ} \mathrm{C}$ per cycle, and $72^{\circ} \mathrm{C}$ for $2 \mathrm{~min}$, and then 36 cycles of $95^{\circ} \mathrm{C}$ for $30 \mathrm{~s}, 58^{\circ} \mathrm{C}$ for $30 \mathrm{~s}$, and $72^{\circ} \mathrm{C}$ for $2 \mathrm{~min}$, with a final extension at $72^{\circ} \mathrm{C}$ for $7 \mathrm{~min}$. PCR products were diluted four times with $\mathrm{MBG}$ water. A mixture of $12 \mu \mathrm{l}$ containing $3 \mu \mathrm{l}$ of PCR product dilution, $7 \mu \mathrm{l}$ of formamide (Applied Biosystems), and $1 \mu \mathrm{l}$ of DNA ladder Genescan 445-LIZ (Applied Biosystems) was denatured at $95^{\circ} \mathrm{C}$ for 5 min and held at $4^{\circ} \mathrm{C}$. The size of the $\mathrm{PCR}$ products was determined using capillary electrophoresis on an ABI3730× DNA Analyzer (Applied Biosystems). The internal molecular weight standard we used was Genescan 445-LIZ (Applied Biosystems). Marker alleles were called using software GeneMarker v2.2.0 (Softgenetics, LLC, State College, PA).

The detection of SP-SNP markers was conducted on a Sequenoum MassARRAY iPLEX platform as described by Xia et al. (2016a). The SNP genotyping reactions consisted of three steps: the iPLEX PCR reaction, the SAP reaction, and the iPLEX Extend reaction. The iPLEX PCR amplification was performed with $1.0 \mu \mathrm{l}$ of $50 \mathrm{ng}$ DNA, $0.5 \mu \mathrm{l}$ of $1 \times$ PCR buffer with $20 \mathrm{mM} \mathrm{MgCl}_{2}, 0.4 \mu \mathrm{l}$ of $25 \mathrm{mM} \mathrm{MgCl}_{2}, 0.1 \mu \mathrm{l}$ of $25 \mathrm{mM}$ dNTPs, $0.5 \mu \mathrm{l}$ of $0.1 \mu \mathrm{M}$ forward PCR primer, $0.5 \mu \mathrm{l}$ of $0.1 \mu \mathrm{M}$ reverse PCR primer, $0.2 \mu \mathrm{l}$ of $5 \mathrm{U}$ of Taq DNA polymerase, and $1.8 \mu \mathrm{l}$ of MBG water in a total volume of $5 \mu \mathrm{l}$. The PCR enzyme was ordered from Roche Diagbostic Inc. (Indianapolis, IN) and other reagents used in the three reaction steps were from Sequenom (San Diego, CA). The reaction was performed at $95^{\circ} \mathrm{C}$ for $2 \mathrm{~min}$, followed by $45 \mathrm{cycles}$, each of $95^{\circ} \mathrm{C}$ for $30 \mathrm{~s}, 56^{\circ} \mathrm{C}$ for $30 \mathrm{~s}$, and $72^{\circ} \mathrm{C}$ for $1 \mathrm{~min}$. The final extension was at $72^{\circ} \mathrm{C}$ for $5 \mathrm{~min}$. After the iPLEX PCR, the shrimp alkaline phosphatase (SAP) reaction was performed by adding $2.0 \mu \mathrm{lmix}$ containing $0.17 \mu \mathrm{l}$ of $10 \times \mathrm{SAP}$ buffer, $0.3 \mu \mathrm{l}$ of $1.7 \mathrm{U} / \mu \mathrm{l}$ SAP enzyme, and $1.53 \mu \mathrm{l}$ of MBG water into the iPLEX PCR product. The SAP reaction was programmed as $37^{\circ} \mathrm{C}$ for $40 \mathrm{~min}$, followed by $85^{\circ} \mathrm{C}$ for $5 \mathrm{~min}$ to inactivate the enzyme. The iPLEX single base extension reaction was performed with an additional 2.0- $\mu$ l mix consisting of $0.2 \mu \mathrm{l}$ of $10 \times$ iPLEX buffer, $0.2 \mu \mathrm{l}$ of iPLEX terminator, $0.94 \mu \mathrm{l}$ of a primer mix containing extension primers with a final concentration of 8,10 , or $15 \mu \mathrm{M}$ depending on the primer mass, and $0.04 \mu \mathrm{l}$ of iPLEX enzyme. The amplification conditions were: $95^{\circ} \mathrm{C}$ for $30 \mathrm{~s}$; followed by 40 cycles, each of which consisted of $94^{\circ} \mathrm{C}$ for $5 \mathrm{~s}$ followed by 5 cycles of $52^{\circ} \mathrm{C}$ for $5 \mathrm{~s}$ and $80^{\circ} \mathrm{C}$ for $5 \mathrm{~s}$; and a final extension at $72^{\circ} \mathrm{C}$ for $3 \mathrm{~min}$. All reactions were conducted in a Veriti 384-Well thermal cycler (Applied Biosystems). After the extension reaction, $16 \mu \mathrm{l}$ of MBG water was added to each well. Ten microliters of resin was added to each well to bind the nonreaction reagents. The iPLEX extension products were dispensed on a SpectroCHIP through a RS1000 Nanodispenser (Sequenom). A matrix-assisted laser desorption/ ionization time-of-flight (MALDI-TOF) mass spectrometer (Sequenom) was then used for detecting SNP alleles. SNP allele calling and clustering were conducted using the MassARRAY TyperAnalyzer software (Sequenom) (Gabriel et al. 2009).

GBS and SNP calling. For GBS analysis, the method described by Poland et al. (2012) was followed. Briefly, DNA samples were quantified using PicoGreen florescence in Synergy (Bio-Tek Instruments, Winooski, VT), normalized to $100 \mathrm{ng} / \mu \mathrm{l}$ and arrayed to 96-well plates. DNA was codigested with enzymes PstI and MspI (New England Biolabs, Ipswich, MA) at $37^{\circ} \mathrm{C}$ for $2 \mathrm{~h}$ for complete digestion followed by $65^{\circ} \mathrm{C}$ for $20 \mathrm{~min}$ to inactivate the enzyme, which generated fragments for ligation with Adapter 1 and Adapter 2 (Y-Adapter) on each respective end of the fragment. The ligation reaction was completed in the same plate. The Pst I overhang corresponds to Adapter 1 and $M s p I$ overhang corresponds to Adapter 2. Adapter 1 consists of a $21 \mathrm{bp}$ of the Ion Forward adapter followed by a 9-bp barcode, a 4-bp 'CGAT' sequence, and a 4-bp 3' overhang of 'TGCA' corresponding to a PstI restriction site. Adapter 2 consists of a 3-bp MspI restriction site,16-bp specific sequence, and a 23-bp unpaired tail sequence for Ion reverse primer adapter. The ligation reaction was performed at $22^{\circ} \mathrm{C}$ for $2 \mathrm{~h}$, and then at $65^{\circ} \mathrm{C}$ for $20 \mathrm{~min}$ to inactivate the enzymes. After ligation, the samples were pooled in 24-plex and purified using the QIAquick PCR purification kit (Qiagen, Valencia, CA). The libraries were then PCR amplified with Ion Forward and Reverse primers, with program at $95^{\circ} \mathrm{C}$ for $30 \mathrm{~s}$; followed by 16 cycles of $95^{\circ} \mathrm{C}$ for $30 \mathrm{~s}, 62^{\circ} \mathrm{C}$ for $20 \mathrm{~s}$, and $68^{\circ} \mathrm{C}$ for $1 \mathrm{~min}$; and a final extension at $72^{\circ} \mathrm{C}$ for $5 \mathrm{~min}$. Following the amplification, the products were again purified using the QIAquick PCR purification kit. The libraries were sequenced on an Ion Proton system using Ion PI Chips at the USDA-ARS Western Regional Small Grain Genotyping Laboratory.

Sequence reads from Fastq files were demultiplexed and the adapter sequences were trimmed. Trimmed reads shorter than $30 \mathrm{bp}$ were discarded. Trimmed reads were mapped against the wholegenome assembly of $P$. striiformis $\mathrm{f}$. sp. tritici race PST-78 (https:// www.broadinstitute.org/). A custom R script was used for calling SNPs. The SNPs with more than $10 \%$ missing data in the progeny isolates were excluded from data analysis.

Data analyses. $\chi^{2}$ test was used to estimate the probability $(P)$ for goodness-of-fit of segregation of avirulence or marker alleles among the progeny isolates to genetic ratios. If a $P$ value was $<0.05$, the testing ratio was rejected. To make the linkage analysis more efficient and mapping more robust, GBS-SNP markers with $P$ value of $>0.1$ were selected.

TABLE 1. Wheat lines with different $Y r$ genes for resistance to stripe rust used in virulence phenotyping isolates of Puccinia striiformis f. sp. tritici

\begin{tabular}{|c|c|c|}
\hline No. & Wheat line & $Y r$ gene \\
\hline \multicolumn{3}{|c|}{ Differentials $^{\mathrm{a}}$} \\
\hline 1 & AvSYr1NIL & Yrl \\
\hline 2 & AvSYr5NIL & Yr5 \\
\hline 3 & AvSYr6NIL & Yr6 \\
\hline 4 & AvSYr7NIL & $Y r 7$ \\
\hline 5 & AvSYr8NIL & $\operatorname{Yr} 8$ \\
\hline 6 & AvSYr9NIL & $\operatorname{Yr} 9$ \\
\hline 7 & AvSYr10NIL & $\operatorname{Yr} 10$ \\
\hline 8 & AvSYr15NIL & $\operatorname{Yr} 15$ \\
\hline 9 & AvSYr17NIL & Yr17 \\
\hline 10 & AvSYr24NIL & $\operatorname{Yr} 24$ \\
\hline 11 & AvSYr27NIL & Yr27 \\
\hline 12 & AvSYr32NIL & Yr32 \\
\hline 13 & AvSYr43NIL & Yr43 \\
\hline 14 & AvSYr44NIL & Yr44 \\
\hline 15 & AvSYrSPNIL & YrSP \\
\hline 16 & AvSYrTr1NIL & $Y r \operatorname{Tr} 1$ \\
\hline 17 & AvS/Exp 1/1-1 Line 74 & YrExp2 \\
\hline 18 & Tyee & $Y r 76^{\mathrm{b}}$ \\
\hline \multicolumn{3}{|c|}{ Supplementary differentials $\mathrm{a}^{\mathrm{a}}$} \\
\hline 19 & Avocet R & $\operatorname{YrA}(\operatorname{Yr} 73, \operatorname{Yr} 74)^{\mathrm{b}}$ \\
\hline 20 & Kalyansona & $Y r 2$ \\
\hline 21 & ТР 981 & Yr25 \\
\hline 22 & AvSYr28NIL & $\operatorname{Yr} 28$ \\
\hline 23 & AvSYr31NIL & Yr31 \\
\hline \multicolumn{3}{|c|}{ Additional $Y r$ single-gene lines } \\
\hline 24 & Yr35/AvSBC2 & Yr35 \\
\hline 25 & Lemhi & $\operatorname{Yr} 21^{\mathrm{b}}$ \\
\hline 26 & CN19 & $\operatorname{Yr} 41^{\mathrm{b}}$ \\
\hline 27 & PI 660056 & $Y r 45^{\mathrm{b}}$ \\
\hline 28 & PI 679598 & $\operatorname{Yr} 53^{\mathrm{b}}$ \\
\hline 29 & Avocet S (AvS) & $Y r 74^{\mathrm{b}}$ \\
\hline
\end{tabular}

a Refer to Wan and Chen (2014) and Wan et al. (2016) for the 18 wheat $Y r$ single-gene lines for differentiating races of $P$. striiformis f. sp. tritici and supplementary differentials.

b Refer to Xiang et al. (2016) for $Y r 76$; Dracatos et al. (2016) for $Y r$ genes present in Avocet R and Avocet S; Luo et al. (2008) for Yr41; Li et al. (2011) for Yr45; Xu et al. (2013) for Yr53; and McIntosh et al. (2013) for other genes. 
Hierarchical agglomerative cluster analysis and principal coordinate analysis (PCoA) were used to assign markers to genetic groups or clusters. Cluster analysis was performed in the $\mathrm{R}$ program using the Ward's method, and PCoA was conducted using the NTSYS-pc program (version 2.2.0.0). Software STRUCTURE version 2.3.4 (Pritchard et al. 2000) was also used to identify groups of molecular markers based on their linkage relationships determined by their genotypes in the progeny population.

Construction of linkage maps. Markers in each cluster, together with the avirulence/virulence data for one-locus phenotypes, were used

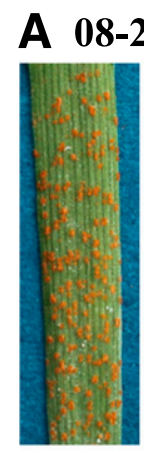

$$
\text { Yr7 }
$$

C

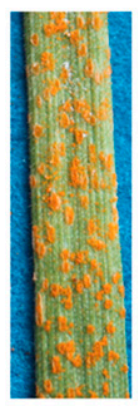

Yr7

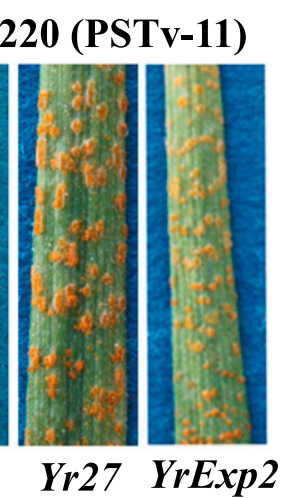

A-6-1

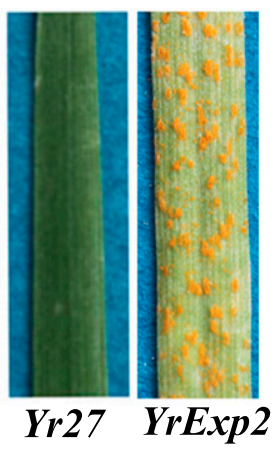

B

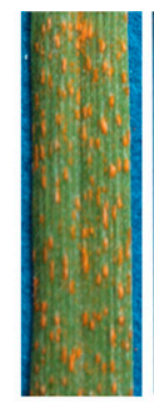

Yr7

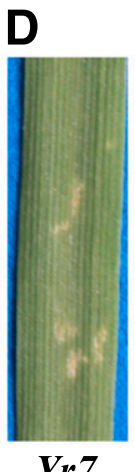

Yr7
A-60-1



Yr27 $\quad$ YrExp2

A-59-1

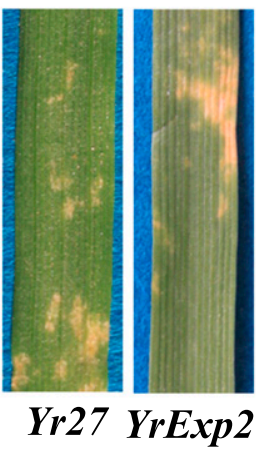

Fig. 1. Phenotypes of the A, parental isolate $08-220$ and progeny isolates $\mathbf{B}$, A-60-1, C, A-6-1, and D, A-59-1 of Puccinia striiformis f. sp. tritici on wheat lines with resistance genes $Y r 7, \operatorname{Yr} 27$, and $\operatorname{YrExp} 2$. to construct linkage maps using software Joinmap (version 4.1) (Van Ooijen 2011). Genetic distances were calculated using the Kosambi mapping function (Kosambi 1944). QTL mapping was performed for the virulence phenotype controlled by two or more loci based on the IT data using the R-qtl package. Using the expectation-maximization algorithm method, standard interval mapping (IM) and composite interval mapping (CIM) were used to detect QTL. LOD thresholds were determined through permutation tests $(n=1,000)$.

\section{RESULTS}

Virulence phenotypes. A total of 119 progeny isolates were obtained through self-fertilizing isolate 08-220. These isolates, together with the parental isolate, were tested on the $29 \mathrm{Yr}$ single-gene lines listed in Table 1. Based on the virulence/avirulence patterns of the progeny isolates on the set of $18 \mathrm{Yr}$ single-gene differentials (Wan and Chen 2014), 49 isolates were identified as race PSTv-11 (virulent to $Y r 1, Y r 6$, $Y r 7, Y r 8, Y r 9, Y r 17, Y r 27, Y r 43, Y r 44, Y r E x p 2$, and $Y r 76$; avirulent on Yr5, Yr10, Yr15, Yr24, Yr32, YrSP, and YrTr1), the same as the parental isolate; 10 isolates as PSTv-71 (virulent to $\operatorname{Yrl}, \operatorname{Yr} 6, \operatorname{Yr} 7, \mathrm{Yr}$ 9, $\mathrm{Yr} 27$, $Y r 43, Y r 44, Y r E x p 2$, and $Y r 76$; avirulent to $Y r 5, Y r 8, Y r 10, Y r 15, Y r 17$, $Y r 24, Y r 32, Y r S P$, and $Y r T r 1$ ), two isolates as PSTv-76 (virulence to $Y r 1$, $Y r 6, Y r 7, Y r 8, Y r 9$, $Y r 17, Y r 27, Y r 43, Y r 44$, and $Y r E x p 2$; avirulent to $Y r 5$, Yr10, Yr15, Yr24, Yr32, YrSP, YrTr1, and Yr76); and the additional 58 isolates as 27 new races (Supplementary Table S3). The progeny isolates were phenotyped on a set of 29 single $\mathrm{Yr}$-gene lines for segregation analysis. The parental isolate and 119 progeny isolates were all avirulent to $Y r 5, Y r 10, Y r 15, Y r 24, Y r 32, Y r S P, Y r T r 1, Y r 45$, and $Y r 53$, indicating that the parental isolate was homozygous avirulent to these nine $Y r$ genes. The parental isolate and 119 progeny isolates were all virulent to $\mathrm{Yr} 41$, indicating that the parental isolate was homozygous virulent to this gene. The parental isolate was virulent (IT 8) to 19 $Y r$ genes, whereas the progeny isolates segregated for avirulence phenotypes to the 19 resistance genes, indicating that the parental isolate is heterozygous for recessive avirulence. As examples, Figure 1 shows the ITs of the parental isolate and three progeny isolates on the wheat lines with $Y r 7, Y r 27$, and $Y r E x p 2$.

Segregation of virulence phenotypes. The inheritance of the 19 virulence phenotypes that segregated among the 119 progeny isolates was studied (Table 2). Eleven virulence phenotypes on wheat lines with $\operatorname{Yr} 1, \operatorname{Yr} 6, \operatorname{Yr} 7, \operatorname{Yr} 8, \operatorname{Yr} 9, \operatorname{Yr} 25, \operatorname{Yr} 27, \operatorname{Yr} 28, \operatorname{Yr} 35$, $Y r A$, or $Y r 74$ fit a 1:3 ratio for avirulence to virulence, indicating that each of these virulence phenotypes was controlled by a single locus,

TABLE 2. Infection types (IT) of the parental isolate (08-220, race PSTv-11) of Puccinia striiformis f. sp. tritici produced on 19 wheat $Y r$ lines and segregation of the 19 virulence loci among its 119 self-crossed progeny isolates

\begin{tabular}{|c|c|c|c|c|c|c|}
\hline \multirow[b]{2}{*}{ Wheat $Y r$ gene line } & \multirow[b]{2}{*}{ IT of $08-220$} & \multicolumn{2}{|c|}{ No. of progeny isolates } & \multirow{2}{*}{$\frac{\text { Exp. ratio }}{(\mathrm{A}: \mathrm{V})}$} & \multirow[b]{2}{*}{$P^{\mathrm{a}}$} & \multirow[b]{2}{*}{ Virulence gene } \\
\hline & & Avirulent & Virulent & & & \\
\hline$Y r 1$ & 8 & 31 & 88 & $1: 3$ & 0.79 & VYrl \\
\hline $\operatorname{Yr6}$ & 8 & 25 & 94 & $1: 3$ & 0.31 & VYr6 \\
\hline $\operatorname{Yr} 7$ & 8 & 31 & 88 & $1: 3$ & 0.79 & $\operatorname{VYr} 7$ \\
\hline $\operatorname{Yr} 8$ & 8 & 36 & 83 & $1: 3$ & 0.19 & VYr8 \\
\hline $\operatorname{Yr} 9$ & 8 & 30 & 89 & $1: 3$ & 0.96 & $\operatorname{VYr} 9$ \\
\hline $\operatorname{Yr} 25$ & 8 & 34 & 85 & $1: 3$ & 0.37 & VYr25 \\
\hline $\operatorname{Yr} 27$ & 8 & 29 & 90 & $1: 3$ & 0.87 & VYr27 \\
\hline $\operatorname{Yr} 28$ & 8 & 35 & 84 & $1: 3$ & 0.27 & VYr 28 \\
\hline Yr35 & 8 & 39 & 80 & $1: 3$ & 0.05 & VYr35 \\
\hline $\operatorname{YrA}(\operatorname{Yr} 73, \operatorname{Yr} 74)$ & 8 & 29 & 90 & $1: 3$ & 0.87 & $\operatorname{VYr} 74$ \\
\hline $\operatorname{Yr} 74(\mathrm{AvS})$ & 8 & 28 & 91 & $1: 3$ & 0.71 & $\operatorname{VYr} 74$ \\
\hline $\operatorname{Yr} 21$ & 8 & 7 & 112 & $1: 15$ & 0.87 & $V Y r 21-1, V Y r 21-2$ \\
\hline Yr31 & 8 & 8 & 111 & $1: 15$ & 0.83 & VYr31-1, VYr31-2 \\
\hline Yr43 & 8 & 5 & 114 & $1: 15$ & 0.36 & VYr43-1, VYr43-2 \\
\hline $\operatorname{Yr} 44$ & 8 & 5 & 114 & $1: 15$ & 0.36 & $V Y r 44-1, V Y r 44-2$ \\
\hline $\operatorname{Yr} 76$ & 8 & 8 & 111 & $1: 15$ & 0.83 & $\operatorname{VYr} 76-1, \operatorname{VYr} 76-2$ \\
\hline $\operatorname{Yr} 17$ & 8 & 56 & 63 & $7: 9$ & 0.47 & $\operatorname{VYr} 17-1, \operatorname{VYr} 17-2$ \\
\hline $\operatorname{YrExp} 2$ & 8 & 46 & 73 & $7: 9$ & 0.26 & VYrExp-1, VYrExp-2 \\
\hline $\operatorname{Yr} 2$ & 8 & 65 & 54 & $7: 9$ & 0.02 & $V Y r 2-1, V Y r 2-2$ \\
\hline $\operatorname{Yr} 2$ & 8 & 65 & 54 & $9: 7$ & 0.72 & Not applicable \\
\hline
\end{tabular}

${ }^{\text {a }} P$, probability of goodness of fit for $\chi^{2}$ test. 
at which the virulence allele was dominant and the avirulent allele was recessive. The genes conferring the virulence phenotypes are therefore, designated as $V Y r 1, V Y r 6, V Y r 7, V Y r 8, V Y r 9, V Y r 25$, VYr27, VYr28, VYr35, VYrA (VYr74), and VYr74, respectively. Virulence phenotypes against five resistance genes $(\operatorname{Yr} 21, \operatorname{Yr} 31$, $Y r 43, Y r 44$, and $Y r 76$ ) fit a 1:15 ratio for avirulence to virulence, indicating that each of the virulence phenotypes was conditioned by two independent loci and the virulence alleles were dominant. These virulence genes are designated as VYr21-1 and VYr21-2; VYr31-1 and VYr31-2; VYr43-1 and VYr43-2; VYr44-1 and VYr442; and $V Y r 76-1$ and $V Y r 76-2$, respectively. The virulence phenotypes to $\operatorname{Yr} 17$ and $\operatorname{YrExp2}$ fit a 7:9 ratio for avirulent to virulent isolates, indicating that each of the virulence phenotypes was controlled by two loci, in which the virulence alleles were dominant and complementary. Thus, the parental isolate is heterozygous at both loci. The genes for virulence phenotypes to these two resistance genes are named as VYr17-1 and VYr17-2, and VYrExp2-1 and VYrExp2-2, respectively. The segregation of the virulence phenotype to $Y r 2$ best fit a 9:7 ratio $(P=0.72)$ for avirulence to virulence, indicating that two loci were involved, at which the virulence alleles were recessive, and the homozygous recessive state at either or both of the loci produced the virulence phenotype. Because this ratio was contradictory to the virulence phenotype of the parental isolate to $Y r 2$, the progeny segregation was also tested for the 7:9 ratio for avirulence and virulence. The observed numbers of avirulent and virulent isolates marginally fit the ratio $(P=0.02)$, and the parental isolate should be heterozygous at both loci. Based on this ratio, the virulence genes are designated as $V Y r 2-1$ and $V Y r 2-2$.

SSR and SP-SNP markers. Of the 173 SSR and 199 SNP markers used to genotype the parental and progeny isolates, 30 SSR and 23 SP-SNP markers were heterozygous in the parental isolate and segregated among the progeny isolates, and the remaining markers were homozygous in the parental isolate and all progeny isolates. As an example, Supplementary Figure S1 shows the two alleles of the SSR marker Pst_gSSR_002 locus in the parental isolate and segregated among some of the progeny isolates. Similarly, Supplementary Figure $\mathrm{S} 2$ is an example showing the segregation of the SP-SNP contig98_01 locus in the progeny population. Of the segregating markers, 19 SSR and 13 SP-SNP markers fit a 1:2:1 ratio for homozygous allele 1, heterozygous, and homozygous allele 2 at each marker locus $(P>0.05)$ (Table 2). The results indicated that these markers were suitable for constructing linkage maps. Except one SP-SNP marker (SP_SNP_426) that fit a 7:8:1 ratio for a twolocus model $(P=0.92)$, the remaining SP-SNP markers did not fit any models for either one locus or two loci, indicating that they were involved in three or more loci and not suitable for mapping.

GBS-SNP markers. To obtain more markers, the 119 progeny isolates, together with the parental isolate, were genotyped using the Ion Proton system. The GBS experiment generated 10,163 SNP markers after filtering out low quality tags. Based on the genetic relationships among the progeny isolates, the 10,163 SNP markers were grouped in six clusters (Supplementary Fig. S3). The results indicated that $P$. striiformis $\mathrm{f}$. sp. tritici has six chromosomes. $\mathrm{CH} 1$ consisted of 2,483 markers, $\mathrm{CH} 2$ consisted of 1,396 markers, $\mathrm{CH} 3$ consisted of

TABLE 3. The numbers of molecular markers and virulence loci in six genetic linkages constructed with simple sequence repeat (SSR), SSR derived from secreted protein genes (SP-SNP), and genotyping-by-sequencing SNP markers

\begin{tabular}{lccc}
\hline $\begin{array}{l}\text { Linkage } \\
\text { group }\end{array}$ & $\begin{array}{c}\text { Number of molecular } \\
\text { markers }\end{array}$ & $\begin{array}{c}\text { Number of } \\
\text { virulence loci }\end{array}$ & $\begin{array}{c}\text { Map distance } \\
(\mathrm{cM})\end{array}$ \\
\hline $\mathrm{CH} 1$ & 52 & 0 & 136.4 \\
$\mathrm{CH} 2$ & 91 & 0 & 74.2 \\
$\mathrm{CH} 3$ & 163 & 0 & 81.0 \\
$\mathrm{CH} 4$ & 166 & 2 & 91.5 \\
$\mathrm{CH} 5$ & 166 & 0 & 65.8 \\
CH6 & 167 & 15 & 148.9 \\
Total & 805 & 17 & 597.8 \\
\hline
\end{tabular}

1,393 markers, $\mathrm{CH} 4$ consisted of 1,793 markers, $\mathrm{CH} 5$ consisted of 1,253 markers, and CH6 consisted of 1,845 markers. The results of PCA and structure analyses confirmed the six genetic groups (Supplementary Figs. S4 and S5).

Linkage maps. To construct a base genetic map for $P$. striiformis f. sp. tritici, 1,072 dominant GBS-SNP markers were selected based on their $P$ values $(>0.1)$ of $\chi^{2}$ test for goodness of fit to the expected 3:1 ratio (presence: absence) for the self-fertilized progeny population. The 1,072 markers, together with 19 SSR and 13 SP-SNP markers, were used in linkage analysis. Of these 1,104 markers, 805 were assigned to linkage groups, whereas 299 were not assigned to any linkages. Using software Joinmap, six linkage groups were constructed with the 805 markers (Supplementary Fig. S6). These linkage groups spanned a total of $597.8 \mathrm{cM}$ (Table 3 ). The six linkage groups corresponded to the six clusters, presumed as six chromosomes. The individual chromosomes contained 52 (chromosome 1) to 167 (chromosome 6), on average 137 markers per linkage group. The genetic lengths of the linkage groups ranged from $65.8 \mathrm{cM}$ (chromosome 5) to $148.9 \mathrm{cM}$ (chromosome 6) with an average genetic distance of $0.73 \mathrm{cM}$ between two loci.

When the virulence loci were integrated into the base map, 17 of the 27 virulence loci (Table 2) were mapped whereas the other 10 were not mapped including the virulence loci to resistance genes $Y r 2$ and $Y r 76$. The mapped virulence loci mainly distributed on chromosomes 4 and 6 (Fig. 2). In chromosome 6, 12 virulence loci (VYr17-1, VYrExp2-1, VYr35, VYr8, VYr25, VYr7, VYr9, VYr74, VYr6, VYr1, VYr27, and VYr28) were clustered to one end of the chromosome within a genetic distance of $35.3 \mathrm{cM}$ without


Fig. 2. Linkage maps of virulence loci of Puccinia striiformis f. sp. tritici constructed with virulence phenotypes and marker genotypes of 119 isolates derived from self-crossing isolate 08-220 (PSTv-11). 
interruption by any molecular markers. The closest marker was GBS-SNP marker B64305, $9.1 \mathrm{cM}$ proximal from the $V Y r 28$ locus. The VYr31-1 locus mapped $26.7 \mathrm{cM}$ away from $V Y r 28$ with nine markers in between, and it was tightly linked with GBS marker B6273 (0.1 cM). In chromosome 6, VYr21-1 mapped $7.5 \mathrm{cM}$ away from $V Y r 31-1$ with six markers in between, and the locus was flanked by GBS markers A212837 (0.2 cM proximal) and B67965 (0.4 cM distal). Using the expectation-maximization algorithm method, two QTL associated with the virulence phenotype to $\mathrm{Yr} 43$ mapped to chromosome 4 using a cutoff value of LOD 3.48. Using the QTL mapping approach, one QTL (VYr43-1) conferring the $Y r 43$ virulence phenotype was mapped in an interval of $4.2 \mathrm{cM}$ flanked by GBS-SNP markers A264254 and A157785, and the other QTL (VYr43-2) for the same virulence phenotype was mapped in an interval of $1.7 \mathrm{cM}$ flanked by GBS-SNP markers $A 417112$ and $A 418952$, which is about $13.5 \mathrm{cM}$ from the first QTL. Other virulence loci were not mapped due to lack of linked markers.

\section{DISCUSSION}

The sexual cycle through alternate hosts provides opportunities for studying genetics of $P$. striiformis f. sp. tritici (RodriguezAlgaba et al. 2014; Tian et al. 2016; Wang et al. 2012; Zhao et al. 2016). In the present study, a sexual population was developed through self-fertilizing $P$. striiformis f. sp. tritici isolate $08-220$ on barberry plants under controlled greenhouse conditions. Through testing the population on a set of $Y r$ single-gene lines and with a large number of molecular markers, we were able to determine the inheritance of virulence, construct a base genetic map, and map a large number of virulence genes. The success of this study is largely attributed to the use of the GBS technique.

The GBS technique has become popular in mapping genes in animals (Bimber et al. 2016) and plants (Li and Erpelding 2016; Lu et al. 2013; Poland et al. 2012; Truong et al. 2012). Few studies have used the approach to study plant pathogenic fungi. Leboldus et al. (2015) used GBS to study Pyrenophora teres f. maculata and Sphaerulin musiva. They identified 5,783 and 2,373 unique loci, containing 16,441 and 9,992 SNPs from natural populations of $P$. teres f. maculata and $S$. musiva, respectively. They used the data generated from the $P$. teres $\mathrm{f}$. maculata natural population in association mapping analysis to map the mating-type gene. They also used a biparental population of $P$. teres $\mathrm{f}$. teres to validate the methodology, and developed a genetic map containing 1,393 SNPs on 997 sequence tags spread across 15 linkage groups.

Our study is the first to use the GBS technology to study genetics and map virulence genes in $P$. striiformis f. sp. tritici. We obtained 10,163 relatively high-quality sequence tags and selected 1,072 SNP markers based on their $P$ values of $>0.1$ in the $\chi^{2}$ tests. Using the selected GBS-SNP, 19 SSR and 13 SP-SNP markers, we were able to construct a base map for $P$. striiformis $\mathrm{f}$. sp. tritici. The base map containing 805 markers consisted of six linkage groups. This is the first genetic map for $P$. striiformis f. sp. tritici, which can serve as a base map for mapping $P$. striiformis f. sp. tritici genes for various traits underlying the biology and pathogenicity of the pathogen, as well as improving assembly of genomic sequences. We used the relatively high $P$ value ( $>0.1)$ as a threshold for high accuracy of the base map and to make mapping more efficient. However, more markers can be included in the map to increase the marker density. Although improvement is needed to reduce missing data, our study demonstrated that GBS is suitable for constructing genetic maps for $P$. striiformis f. sp. tritici and other fungi.

In this study, we identified six clusters for the 10,163 GBS-SNP markers. The six groups were supported by PCA of these markers, and further supported by the linkage analysis with selected 1,072 markers. Therefore, we suggest that the six clusters represent six chromosomes in the haploid genome of $P$. striiformis f. sp. tritici. The number agrees with a previous report for $P$. striiformis. Using Giemsa-HCl-stained preparation of germ tubes from urediniospores and phase contrast microscopy, Goddard (1976) observed six chromosomes in mitotic figures of dividing nuclei during germ tube mitosis and the 12 chromatids were observed on several occasions. To our knowledge, Goddard's study and the present study are the only ones reporting the number of chromosomes for the stripe rust fungus. For other cereal rust fungi, different numbers were reported using different techniques. Early microscopic studies almost all reported six chromosomes as the haploid number. McGinnis (1953) reported that $P$. graminis had six chromosomes in the haploid stage, and this was confirmed by Williams and Hartley (1971) who found 12 chromosomes in the dikaryon stage, and Maclean et al. (1971) who observed six chromosomes in axenic cultures. In $P$. coronata $\mathrm{f}$. sp. secalis and P. coronata f. sp. calamagrostis, McGinnis (1954, 1956) observed three chromosomes during mitotic metaphase. Based on repeat observations of chromosomes during prophase and metaphase in apical cells of dikaryotic hyphae in infected leaves, Valkoun and Bartoš (1974) reported six chromosomes as haploid number in P. triticina. However, through reconstructing images from transmission electron microscopy of serial sections through meiotic nuclei at first pachytene in teliospores, Boehm and Bushnell (1992) and Boehm et al. (1992) reported that the haploid chromosome number for $P$. graminis is 18, the same as that of Melampsora lini. Similarly, the numbers of chromosomes in $P$. coronata, $P$. triticina, and $P$. recondita are in the range of 16 to 20 chromosomes (Leonard and Szabo 2005). It is not clear whether the different numbers are due to different isolates or due to different techniques. Although the real number for each of the species need to be determined by more accurate techniques, we believe that $P$. striiformis f. sp. tritici has 6 haploid chromosomes and 12 chromosomes in dikaryotic cells, as our result agreed with Goddard's report, although different approaches were used. This chromosome number result is useful for understanding the $P$. striiformis $\mathrm{f}$. sp. tritici genome structure and future studies for molecular mapping of genes conferring various traits of the fungus.

From the 119 progeny isolates, we identified 27 different races based on the 18 wheat $\mathrm{Yr}$ single-gene differentials (Wan and Chen 2014; Wan et al. 2016). Of the 27 races, 3 races were similar to previously identified races including PSTV-11 of the parental isolate (with 49 progeny isolates), PSTv-71 (with 10 progeny isolates), and PST-76 (with 2 progeny isolate). The possibility of contamination for the 49 isolates with the similar race to the parental isolate was ruled out by their different molecular genotypes and for those similar to PSTv-71 by the fact that PSTV-71 isolates were not used in any tests in 2015 during which the sexual population was obtained and tested with the wheat lines. The resemblance of such a high number of progeny isolates to the parental isolate is likely due to the linkages of the virulence loci. With the phenotype data in response to 11 additional $\mathrm{Yr}$ single-gene lines, the number of virulence pathotypes was greater (data not shown). This result confirmed the previous reports that $P$. striiformis $\mathrm{f}$. $\mathrm{sp}$. tritici is a heteroecious and macrocyclic fungus (Jin et al. 2010; Wang and Chen 2013; Zhao et al. 2013), and if it occurs, sexual reproduction can produce new races under either controlled conditions (RodriguezAlgaba et al. 2014; Wang et al. 2012) or natural conditions (Wang et al. 2016; Zhao et al. 2013).

In the present study, we determined the inheritance of virulence phenotypes to 19 resistance genes. Virulence to 11 of the resistance genes each was controlled by a single dominant gene and virulence to the remaining eight resistance genes each was controlled by either two independent dominant genes or two complementary dominant genes. Thus, a total of 27 virulence genes were identified. It is interesting that almost all of the virulence genes were dominant. Traditionally, avirulence is considered dominant and its product interacts either directly or indirectly with the product from its corresponding resistance gene to have an incompatible interaction, in which the pathogen is avirulent and the plant is resistant (Hammond-Kosack and Jones 1997; Miglani 2002; Van Der Biezen and Jones 1998). However, avirulence can be either dominant or recessive based on results from genetic studies. Single dominant 
genes for avirulence have been reported in $P$. graminis f. sp. tritici, $P$. graminis f. sp. avenae, $P$. triticina, and P. cronata (Green 1965; Newton and Johnson 1932; Newton et al. 1930; Statler 2000; Statler and Jin 1991; Zambino et al. 2000). Recessive avirulence is not uncommon. Statler and Jin (1991) reported single recessive avirulence genes in $P$. triticina, and other researchers also reported recessive avirulence genes in P. graminis f. sp. avenae (Green 1965; Green and McKenzie 1967; Martens et al. 1970). In addition to the reports of a single gene for an avirulence phenotype, some individual avirulence phenotypes have been found to be controlled by two genes. Statler (2000) showed that the virulence/virulence phenotypes of Pt to Lr3, $L r 11, L r 16, L r 21, L r 26$, and $L r 30$ segregated at a ratio of 15:1, indicating two independent dominant genes (Statler 2000). Other studies also identified avirulence phenotypes controlled by two independent dominant genes in P. triticina (Samborski and Dyck 1968, 1976; Statler and Jin 1991). In P. graminis f. sp. tritici, the avirulence to $\mathrm{Sr}$ ( $\mathrm{Sr}$ fleck) (Zambino et al. 2000) and the avirulence to wheat cultivar Vernal were reported to be controlled by two independent dominant genes (Johnson and Newton 1940). Some avirulence phenotypes are controlled by two complementary genes, with one gene dominant for avirulence loci and another gene dominant for suppression of avirulence, as reported in P. graminis f. sp. tritici (Zambino et al. 2000), P. triticina (Haggag et al. 1973), and P. coronata (Biali and Dinoor 1972). In the present study, we did not identify dominant avirulence genes and suppressers, but identified recessive genes for avirulence phenotypes, and when two genes are involved, they acted either independent or in complementary fashion.

The interactions between a plant host and a pathogen can be complex. For resistance to stripe rust, both dominant and recessive genes have been reported in wheat (Biffen 1905; Chen and Line 1992, 1993; Lupton and Macer 1962; Röbbelen and Sharp 1978). In barley, most genes for resistance to stripe rust were found to be recessive (Chen and Line 1999). The inheritance of virulence in P. striiformis f. sp. tritici has not been well studied because of the lack of knowledge on sexual reproduction until the recent findings of alternate hosts for the fungus (Jin et al. 2010; Wang and Chen 2013; Zhao et al. 2013). Rodriguez-Algaba et al. (2014) reported a study with only 16 progeny isolates obtained by self-fertilizing a European $P$. striiformis f. sp. tritici isolate. They did not find segregation in the progeny isolate for most virulence phenotypes of the parental isolates, including those to resistance genes $\mathrm{Yr} 1, \mathrm{Yr} 2$, $\operatorname{Yr} 6, Y r 7, Y r 9$, and $Y r S P$ that were tested in the present study. They also did not detect segregation in the progeny isolates for the avirulence phenotypes to resistance genes $\operatorname{Yr} 5, \mathrm{Yr} 10, \mathrm{Yr} 15, \mathrm{Yr} 24$, and $Y r 27$ of the parental isolate, which were similar to our results, except $Y r 27$. They only observed segregation for the parental avirulence phenotype to $Y r 8$ and for the moderate virulence phenotype to $\operatorname{Yr} 17$. The lack of heterozygous avirulence/virulence loci in the parental isolate did not allow the authors to determine the number of genes and inheritance of virulence. Using a sexual population of 118 isolates developed by self-fertilizing a Chinese $P$. striiformis f. sp. tritici isolate, Tian et al. (2016) determined the inheritance of virulence to eight resistance genes. They found that avirulence phenotypes to three resistance genes ( $\mathrm{r} 6, \mathrm{Yr} 43$, and $Y r S P$ ) were controlled by single dominant genes whereas the virulence phenotypes were recessive, and the avirulence phenotypes to the remaining five resistance genes were controlled either by a single recessive gene (to $Y r 27$ and $Y r 28$ ) or two complementary recessive genes $(\mathrm{Yr} 4, \mathrm{Yr} 32$, and $\mathrm{Yr} 44)$. Similar to our results, their results also indicate that avirulence genes in $P$. striiformis $\mathrm{f}$. sp. tritici are likely recessive whereas virulence alleles are likely dominant. The difference in dominant/recessive expression and the number of genes involved in our study and the previous studies are due to different $P$. striiformis $\mathrm{f}$. sp. tritici isolates used. Similar differences have been reported in $P$. triticina. For example, the virulence phenotypes to leaf rust resistance genes $\operatorname{Lr} 3, \mathrm{Lr} 10$, and Lr30 had different inheritance modes. Statler (2000) and Statler and Jin (1991) observed that an $F_{2}$ population segregated as 3 avirulent:
1 virulent on wheat line with $\operatorname{Lr} 3$ and 9:7 on wheat lines with $\operatorname{Lr} 30$, and in contrast, another $F_{2}$ population segregated as 15 avirulent: 1 virulent to $L r 3$ and $15: 1$ to $L r 30$. Statler (1977) found a single dominant gene conditioning virulence to $\mathrm{Lr} 10$, but later he identified a digenic recessive ratio for virulence to the same gene using a different $P$. triticina culture (Statler 1982). These results suggest that inheritance of avirulence/virulence is dependent on specific rust isolates. Different isolates either have different genes conditioning avirulence/virulence or some isolates may have additional epistatic genes or entirely different genes conferring avirulence/virulence. In comparison with previous genetic studies with $P$. striiformis $\mathrm{f}$. sp. tritici, our study has so far identified the highest number of virulence genes and revealed their modes of inheritance. Our results also indicate that the interactions between wheat resistance genes and $P$. striiformis f. sp. tritici virulence/avirulence genes are more complex than the previous hypotheses of dominant avirulence genes and the one-gene-for-one-gene relationship. How the $P$. striiformis $\mathrm{f}$. sp. tritici recessive avirulence genes or dominant virulence genes interact with dominant or recessive resistance genes of wheat requires further studies. To better understand the host-pathogen interactions, genes for avirulence/virulence in $P$. striiformis $\mathrm{f}$. $\mathrm{sp}$. tritici should be cloned and the mechanisms of their interactions with plant genes should be studied.

With the relatively high density of the base map, we were able to map 17 out of the 27 virulence genes identified in the present study. All 17 genes mapped to only two chromosomes. Chromosome 6 harbors 14 genes with 12 of them linked in one terminal region. The three virulence genes (VYr43-1, VYr43-2, and VYr44-1) were separated by several markers on chromosome 4. Similar to our findings, Statler $(1977,1982,2000)$ found avirulence/virulence loci $p 2, p 17$, and $p 18$ in P. triticina were linked. Tian et al. (2016) also found that the virulence/virulence loci to $\mathrm{Yr} 43$ and $\mathrm{Yr} 44$ were in the same linkage group. Tightly linked markers $(<10.0 \mathrm{cM})$ were identified for VYr31-1 (B6273, $0.1 \mathrm{cM}$ ), VYr21-1 (A212837, 0.2 cM; B67965, $0.4 \mathrm{cM}$ ), and VYr43-1 (flanked by A417112 and A418952 within $1.7 \mathrm{cM}$ ). In addition, GBS markers that were not included in the linkage analysis but had $\chi^{2}$ test $P$ values greater than 0.05 can be further explored to find more markers associated to these mapped virulence genes and the remaining unmapped genes. Tightly linked or highly associated markers may be used as starting points to clone these genes. Fully characterized virulence genes should improve the understanding of the wheat $-P$. striiformis $\mathrm{f}$. sp. tritici interactions and the information can be used to select effective resistance genes for better combinations to be used in breeding wheat cultivars with effective and durable resistance to stripe rust.

\section{ACKNOWLEDGMENTS}

This study was supported by the U.S. Department of Agriculture, Agricultural Research Service (Project 2090-22000-018-00D), Washington Grain Commission, and Idaho Wheat Commission. PPNS Number 0743, Department of Plant Pathology, College of Agricultural, Human, and Natural Resource Sciences, Agricultural Research Center, Project Number WNP00663 (Projects 13C-3061-5682; 13C-3061-4232), Washington State University, Pullman, WA 99164-6430. The China Scholarship Council scholarship to C. Yuan is greatly appreciated.

\section{LITERATURE CITED}

Bailey, J., Karaoglu, H., Wellings, C., and Park, R. 2013. Isolation and characterization of 25 genome-derived simple sequence repeat markers for Puccinia striiformis f. sp. tritici. Mol. Ecol. Resour. 13:760-762.

Biali, M., and Dinoor, A. 1972. Genetics of virulence in Puccinia coronata. Page 103-108 in: Proc. 3rd Eur. Mediterr. Cereal Rusts Conf., Research Institute of Crop Protection, Praha, Czechoslovakia.

Biffen, R. H. 1905. Mendel's laws of inheritance and wheat breeding. J. Agric. Sci. 1:4-48.

Bimber, B. N., Raboin, M. J., Letaw, J., Nevonen, K. A., Spindel, J. E., McCouch, S. R., Cervera-Juanes, R., Spindel, E., Carbone, L., Ferguson, B., and Vinson, A. 2016. Whole-genome characterization in pedigreed non-human 
primates using genotyping-by-sequencing (GBS) and imputation. BMC Genomics 17:676.

Boehm, E. W. A., and Bushnell, W. R. 1992. An ultrastructural pachytene karyotype for Melampsora lini. Phytopathology 82:1212-1218.

Boehm, E. W. A., Wenstrom, J. C., McLaughlin, D. J., Szabo, L. J., Roelfs, A. P., and Bushnell, W. R. 1992. An ultrastructural pachytene karyotype for Puccinia graminis f. sp. tritici. Can. J. Bot. 70:401-413.

Chen, C. Q., Zheng, W. M., Buchenauer, H., Huang, L. L., Lu, N. H., and Kang, Z. S. 2009. Isolation of microsatellite loci from expressed sequence tag library of Puccinia striiformis f. sp. tritici. Mol. Ecol. Resour. 9:236-238.

Chen, X. M. 2005. Epidemiology and control of stripe rust [Puccinia striiformis f. sp. tritici] on wheat. Can. J. Plant Pathol. 27:314-337.

Chen, X. M. 2013. High-temperature adult-plant resistance, key for sustainable control of stripe rust. Am. J. Plant Sci. 4:608-627.

Chen, X. M. 2014. Integration of cultivar resistance and fungicide application for control of wheat stripe rust. Can. J. Plant Pathol. 36:311-326.

Chen, X. M., and Line, R. F. 1992. Inheritance of stripe rust resistance in wheat cultivars used to differentiate races of Puccinia striiformis in North America. Phytopathology 82:633-637.

Chen, X. M., and Line, R. F. 1993. Inheritance of stripe rust resistance in wheat cultivars postulated to have resistance gene at $\mathrm{Yr} 3$ and $\mathrm{Yr} 4$ loci. Phytopathology 83:382-388.

Chen, X. M., and Line, R. F. 1999. Recessive genes for resistance to races of Puccinia striiformis f. sp. hordei in barley. Phytopathology 89:226-232.

Chen, X. M., Moore, M. K., Milus, E. A., Long, D. L., Line, R. F., Marshall, D., and Jackson, L. 2002. Wheat stripe rust epidemics and races of Puccinia striiformis f. sp. tritici in the United States in 2000. Plant Dis. 86: 39-46.

Chen, X. M., Penman, L., Wan, A. M., and Cheng, P. 2010. Virulence races of Puccinia striiformis f. sp. tritici in 2006 and 2007 and development of wheat stripe rust and distributions, dynamics, and evolutionary relationships of races from 2000 to 2007 in the United States. Can. J. Plant Pathol. 32: 315-333.

Cheng, P., Chen, X. M., Xu, L. S., and See, D. R. 2012. Development and characterization of expressed sequence tag-derived microsatellite markers for the wheat stripe rust fungus Puccinia striiformis f. sp. tritici. Mol. Ecol. Resour. 12:779-781.

Dracatos, P. M., Zhang, P., Park, R. F., McIntosh, R. A., and Wellings, C. R. 2016. Complementary resistance genes in wheat selection 'Avocet R' confer resistance to stripe rust. Theor. Appl. Genet. 129:65-76.

Enjalbert, J., Duan, X., Giraud, T., Vaurtin, D., de Vallavieille-Pope, C., and Solignac, M. 2002. Isolation of 12 microsatellite loci, using an enrichment protocol, in the phytopathogenic fungus Puccinia striiformis f. sp. tritici. Mol. Ecol. Notes 2:563-565.

Flor, H. H. 1965. Tests for allelism of rust-resistance genes in flax. Crop Sci. 5: 415-418.

Gabriel, S., Ziaugra, L. and Tabbaa, D. 2009. SNP genotyping using the Sequenom MassARRAY iPLEX platform. Curr. Protoc. Human Genet. 60: 2.12.1-2.12.16.

Goddard, M. V. 1976. Cytological studies of Puccinia striiformis (yellow rust of wheat). Trans. Br. Mycol. Soc. 66:433-437.

Green, G. J. 1965. Inheritance of virulence in oat stem rust on the varieties Sevnothree, Richland and White Russian. Can. J. Genet. Cytol. 7:641-650.

Green, G. J., and McKenzie, R. I. H. 1967. Mendelian and extrachromosomal inheritance of virulence in Puccinia graminis f. sp. avenae. Can. J. Genet. Cytol. 9:785-793.

Haggag, M. E. A., Samborski, D. J., and Dyck, P. L. 1973. Genetics of pathogenicity in three races of leaf rust on four wheat varieties. Can. J. Genet. Cytol. 15:73-82.

Hammond-Kosack, K. E., and Jones, J. D. G. 1997. Plant disease resistance genes. Annu. Rev. Plant Physiol. Plant Mol. Biol. 48:575-607.

Jin, Y., Szabo, L. J., and Carson, M. 2010. Century-old mystery of Puccinia striiformis life history solved with the identification of Berberis as an alternate host. Phytopathology 100:432-435.

Johnson, R. 1981. Durable resistance, definition of genetic control, and attainment in plant breeding. Phytopathology 71:567-568.

Johnson, T., and Newton, M. 1940. Mendelian inheritance of certain pathogenic characters of Puccinia graminis tritici. Can. J. Res. C18:599-611.

Kosambi, D. D. 1944. The estimation of map distances from recombination values. Ann. Eugen. 12:172-175.

Leboldus, J. M., Kinzer, K., Richards, J., and Brueggeman, R. S. 2015. Genotype-by-sequencing of the plant pathogenic fungi Pyrenophora teres and Sphaerulina musiva utilizing Ion Torrent sequence technology. Mol. Plant Pathol. 16:623-632.

Leonard, K. J., and Szabo, L. J. 2005. Stem rust of small grains and grasses caused by Puccinia graminis. Mol. Plant Pathol. 6:99-111.

Li, Q., Chen, X. M., Wang, M. N., and Jing, J. X. 2011. Yr45, a new wheat gene for stripe rust resistance on the long arm of chromosome 3D. Theor. Appl. Genet. 122:189-197.
Li, R., and Erpelding, J. E. 2016. Genetic diversity analysis of Gossypium arboreum germplasm accessions using genotyping-by-sequencing. Genetica 144:535-545.

Line, R. F. 2002. Stripe rust of wheat and barley in North America: A retrospective historical review. Annu. Rev. Phytopathol. 40:75-118.

Line, R. F., and Qayoum, A. 1992. Virulence, aggressiveness, evolution, and distribution of races of Puccinia striiformis (the cause of stripe rust of wheat) in North America, 1968-87. USDA-ARS Tech. Bull. 1788.

Loegering, W. Q. 1978. Current concepts in interorganismal genetics. Annu. Rev. Phytopathol. 16:309-320.

Lu, F., Lipka, A. E., Glaubitz, J., Elshire, R., Cherney, J. H., Casler, M. D., Buckler, E. S., and Costich, D. E. 2013. Switchgrass genomic diversity, ploidy, and evolution: Novel insights from a network-based SNP discovery protocol. PLoS Genet. 9:e1003215.

Luo, P. G., Hu, X. Y., Ren, Z. L., Zhang, H. Y., Shu, K., and Yang, Z. J. 2008. Allelic analysis of stripe rust resistance genes on wheat chromosome $2 \mathrm{BS}$. Genome 51:922-927.

Lupton, F. C. H., and Macer, R. C. F. 1962. Inheritance of resistance to yellow rust (Puccinia glumarum Erikss. and Henn.) in seven varieties of wheat. Trans. Br. Mycol. Soc. 45:21-45.

Maclean, D. J., Scott, K. J., and Tommerup, I. C. A. 1971. A uninucleate wheat-infecting strain of the stem rust fungus isolated from axenic cultures. J. Gen. Microbiol. 65:339-342.

Martens, J. W., McKenzie, R. I. H., and Green, G. J. 1970. Gene-for-gene relationships in the Avena: Puccinia graminis host-parasite system in Canada. Can. J. Bot. 48:969-975.

McDowell, J. M., and Woffenden, B. J. 2003. Plant disease resistance genes: Recent insights and potential applications. Trends Biotechnol. 21: 178-183.

McGinnis, R. G. 1953. Cytological studies of chromosomes of rust fungi. I. The mitotic chromosomes of Puccinia graminis. Can. J. Bot. 31:522-526.

McGinnis, R. G. 1954. Cytological studies of chromosomes of rust fungi. II. The mitotic chromosomes of Puccinia coronata. Can. J. Bot. 32:213-214.

McGinnis, R. G. 1956. Cytological studies of chromosomes of rust fungi. III. The relationship of chromosome number to sexuality in Puccinia. J. Hered. 47:255-259.

McIntosh, R. A., Yamazaki, Y., Dubcovsky, J., Rogers, J., Morris, C., Appels, R., and Xia, X. C. 2013. Catalogue of gene symbols for wheat. 12th Int. Wheat Genet. Symp., Yokohama, Japan. http://shigen.nig.ac.jp/wheat/komugi/genes/ download.jsp

Miglani, G. S. 2002. Advanced Genetics. Alpha Science International Ltd., Pangbourne, England.

Newton, M., and Johnson, T. 1932. Studies in cereal diseases VIII: Specialization and hybridization of wheat stem rust, Puccinia graminis tritici, in Canada. Can. Dep. Agric. Bull. 160.

Newton, M., Johnson, T., and Brown, A. M. 1930. A study of the inheritance of spore colour and pathogenicity in crosses between physiologic forms of Puccinia graminis tritici. Sci. Agric. 10:775-798.

Poland, J. A., Brown, P. J., Sorrells, M. E., and Jannink, J. L. 2012. Development of high-density genetic maps for barley and wheat using a novel two-enzyme genotyping-by-sequencing approach. PLoS One 7:e32253.

Pritchard, J. K., Stephens, M., and Donnelly, P. 2000. Inference of population structure using multilocus genotype data. Genetics 155:945-959.

Röbbelen, G., and Sharp, E. L. 1978. Mode of inheritance, interaction and application of genes conditioning resistance to yellow rust. Pages 1-88 in: Advances in Plant Breeding. H. W. Hannover and G. G. Röbbelen, eds. Pflanzenzucht 9:88.

Rodriguez-Algaba, J., Walter, S., Sørensen, C. K., Hovmøller, M. S., and Justesen, A. F. 2014. Sexual structures and recombination of the wheat rust fungus Puccinia striiformis on Berberis vulgaris. Fungal Genet. Biol. 70:77-85.

Rosewarne, G. M., Herrera-Foessel, S. A., Singh, R. P., Huerta-Espino, J., Lan, C. X., and He, Z. H. 2013. Quantitative trait loci of stripe rust resistance in wheat. Theor. Appl. Genet. 126:2427-2449.

Samborski, D. J., and Dyck, P. L. 1968. Inheritance of virulence in wheat leaf rust on the standard differential wheat varieties. Can. J. Genet. Cytol. 10:24-32.

Samborski, D. J., and Dyck, P. L. 1976. Inheritance of virulence in Puccinia recondita on six backcross lines of wheat with single genes for resistance to leaf rust. Can. J. Bot. 54:1666-1671.

Schuelke, M. 2000. An economic method for the fluorescent labeling of PCR fragments. Nat. Biotechnol. 18:233-234.

Statler, G. D. 1977. Inheritance of virulence of culture 73-47 Puccinia recondita. Phytopathology 67:906-908.

Statler, G. D. 1982. Inheritance of virulence of Puccinia recondita f. sp. tritici on durum and spring wheat cultivars. Phytopathology 72:210-213.

Statler, G. D. 2000. Inheritance of virulence of Puccinia triticina culture X47, the $F_{1}$ of the cross 71-112×70-1. Can. J. Plant Pathol. 22:276-279.

Statler, G. D., and Jin, Y. 1991. Inheritance of virulence of Puccinia recondita culture X43. Can. J. Plant Pathol. 13:33-37.

Tian, Y., Zhan, G. M., Chen, X. M., Tungruentragoon, A., Lu, X., Zhao, J., Huang, L. L., and Kang, Z. S. 2016. Virulence and SSR marker segregation 
in a Puccinia striiformis f. sp. tritici population produced by selfing a Chinese isolate on Berberis shensiana. Phytopathology 106:185-191.

Truong, H. T., Ramos, A. M., Yalcin, F., de Ruiter, M., van der Poel, H. J. A., Huvenaars, K. H. J., Hogers, R. C. J., van Enckevort, L. J. G., Janssen, A., van Orsouw, N. J., and van Eijk, M. J. T. 2012. Sequence-based genotyping for marker discovery and co-dominant scoring in germplasm and populations. PLoS One 7:e37565.

Valkoun, J., and Bartoš, P. 1974. Somatic chromosome number in Puccinia recondita. Trans. Br. Mycol. Soc. 63:187-189.

Van Der Biezen, E., and Jones, J. D. G. 1998. Plant disease-resistance proteins and the gene-for-gene concept. Trends Biochem. Sci. 23:454-456.

Van Ooijen, J. W. 2011. Multipoint maximum likelihood mapping in a full-sib family of an outbreeding species. Genet. Res. 93:343-349.

Wan, A. M., and Chen, X. M. 2012. Virulence, frequency, and distribution of races of Puccinia striiformis f. sp. tritici and $P$. strifformis $\mathrm{f}$. $\mathrm{sp}$. hordei identified in the United States in 2008 and 2009. Plant Dis. 96:67-74.

Wan, A. M., and Chen, X. M. 2014. Virulence characterization of Puccinia striiformis f. sp. tritici using a new set of $Y r$ single-gene line differentials in the United States in 2010. Plant Dis. 98:1534-1542.

Wan, A. M., Chen, X. M., and Yuen, J. 2016. Races of Puccinia striiformis f. sp. tritici in the United States in 2011 and 2012 and comparison with races in 2010. Plant Dis. 100:966-975.

Wang, M. N., and Chen, X. M. 2013. First report of Oregon grape (Mahonia aquifolium) as an alternate host for the wheat stripe rust pathogen (Puccinia striiformis f. sp. tritici) under artificial inoculation. Plant Dis. 97:839.

Wang, M. N., and Chen, X. M. 2015. Barberry does not function as an alternate host for Puccinia striiformis f. sp. tritici in the U.S. Pacific Northwest due to teliospore degradation and barberry phenology. Plant Dis. 99:1500-1506.

Wang, M. N., Wan, A. M., and Chen, X. M. 2012. Genetic characterization of virulence/avirulence genes of Puccinia striiformis f. sp. tritici. Phytopathology 102(Suppl. 4):S132.

Wang, Z. Y., Zhao, J., Chen, X. M., Peng, Y. L., Ji, J. J., Zhao, S. L., Lu, Y. J., Huang, L. L., and Kang, Z. S. 2016. Virulence variations of Puccinia striiformis f. sp. tritici isolates collected from Berberis spp. in China. Plant Dis. 100:131-138.
Wellings, C. R. 2011. Global status of stripe rust: a review of historical and current threats. Euphytica 179:129-141.

Wellings, C. R., Singh, R. P., McIntosh, R. A., and Pretorius, Z. A. 2004. The development and application of near isogenic lines for the stripe (yellow) rust pathosystem. Page A1.39 in: Proc. 11th Intl. Cereal Rusts and Powdery Mildew Conf., Norwich, England.

Williams, P. G., and Hartley, M. J. 1971. Occurrence of diploid lines of Puccinia graminis tritici in axenic culture. Nature 229:181-182.

Xia, C. J., Wan, A. M., Wang, M. N., Jiwan, D. A., See, D. R., and Chen, X. M. 2016a. Secreted protein gene derived-single nucleotide polymorphisms (SPSNPs) reveal population diversity and differentiation of Puccinia striiformis f. sp. tritici in the United States. Fungal Biol. 120:729-744.

Xia, C. J., Wang, M. N., Wan, A. M., Jiwan, D. A., See, D. R., and Chen, X. M. 2016b. Association analysis of SP-SNPs and avirulence genes in Puccinia striiformis f. sp. tritici, the wheat stripe rust pathogen. Am. J. Plant Sci. 7: 126-137.

Xiang, C., Feng, J. Y., Wang, M. N., Chen, X. M., See, D. R., Wan, A. M., and Wang, T. 2016. Molecular mapping of stripe rust resistance gene $Y r 76$ in winter club wheat cultivar Tyee. Phytopathology 106:1186-1193.

Xu, L. S., Wang, M. N., Cheng, P., Kang, Z. S., Hulbert, S. H., and Chen, X. M. 2013. Molecular mapping of Yr53, a new gene for stripe rust resistance in durum wheat accession PI480148 and its transfer to common wheat. Theor. Appl. Genet. 126:523-533.

Zambino, P. J., Kubelik, A. R., and Szabo, L. J. 2000. Gene action and linkage of avirulence genes to DNA markers in the rust fungus Puccinia graminis. Phytopathology 90:819-826.

Zhao, J., Wang, L., Wang, Z. Y., Chen, X. M., Zhang, H. C., Yao, J. N., Zhan, G. M., Chen, W., Huang, L. L., and Kang, Z. S. 2013. Identification of eighteen Berberis species as alternate hosts of Puccinia striiformis f. sp. tritici and virulence variation in the pathogen isolates from natural infection of barberry plants in China. Phytopathology 103:927-934.

Zhao, J., Wang, M. N., Chen, X. M., and Kang, Z. 2016. Role of alternate hosts in epidemiology and pathogen variation of cereal rusts. Annu. Rev. Phytopathol. 54:207-228. 